\title{
PERANAN MAJELIS DESA PAKRAMAN BALI DALAM PELAKSANAAN INVESTASI KEPARIWISATAAN DI WILAYAH DESA PAKRAMAN ${ }^{1}$
}

\author{
Oleh: \\ Dewa Nyoman Gede Suatmaja ${ }^{2}$
}

\begin{abstract}
This description aims to examine the role of the village council (MDP) Bali in implementing tourism investment in the rural area.After doing some assessments in normative legal research methods, finally can be concluded as follows: First, the trigged factor of implementation of tourism investment in rural area of pakraman are (a) The natural beauty and top valeu of its unique culture and social condition. (b) Government policies and regulation that support the implementation of tourism investments in rural areas of pakraman. (c) On the other side, desa pakraman with awigawig (local Rules) owned can be a controlling factor for the implementation of tourism investments in its territory. Second, MDP Bali unable to participate directly in the implementation of tourism investment in rural area of pakraman caused the implementation of tourism investment in the region is a matter of autonomy of desa pakraman concerned. MDP Bali can only play a role: (A). Providing a advices, suggestions and option to any interested parties; $(B)$. encourage desa pakraman in controlling the investment in its region. The impetus is stipulated in MDP Bali decree No 050/Kep/PSM-1/ MDP Bali/III/2006, that any investment in the region of pakraman must receive a recommendatoin from desa pakraman.Third, Efforts can be made by MDP Bali in conflict resolution at that field of tourism investment within the region of pakraman is mediating the setllement of the conflict conducted by the parties.
\end{abstract}

Keywords: Pakraman Bali Assembly, Tourism Investmen, Pakraman Village

Abstrak
Tulisan ini bertujuan untuk mengkaji peranan Majelis Desa Pakraman(MDP)Bali
dalam pelaksanaan investasi kepariwisataan di wilayah desa pakraman.Setelah
dilakukan pengkajian dengan metode penelitian hukum normatif, akhirnya dapat
disimpulkan sebagai berikut. Pertama, faktor penarik pelaksanaan investasi
kepariwisataan di wilayah desa pakraman meliputi (a) keindahan alam dan kondisi
sosial budaya yang unik dan bernilai tinggi; (b) faktor kebijakan dan regulasi
pemerintah yang mendukung pelaksaaan investasi di wilayah desa pakraman; dan
(c) di sisi lain desa pakraman dengan awig-awig yang dimilikinya dapat menjadi
faktor pengendali bagi pelaksanaan investasi di wilayahnya. Kedua, MDP Bali
tidak dapat berperan secara langsung dalam pelaksanaan kepariwisataan di
wilayah desa pakraman, sebab pelaksanaan investasi di wilayah desa pakraman
1 Artikel ini merupakan karyailmiah mahasiswa pada Program Studi Magister(S2) Ilmu Hukum Program
Pascasarjana Universitas Udayana, serta mengucapkan terimakasih kepada Prof. Dr. I Nyoman Sirtha,
SH.,MS dan Dr. I Ketut Sudantra, SH.,MH selaku Pembimbing Tesis.
2 Mahasiswa Program Magister Universitas Udayana, Denpasar, Bali, e-mail: balibanana@hotmail.
com 
merupakan urusan otonomi desa pakraman yang bersangkutan. MDP Bali hanya dapat berperan: (a) memberi saran, usul dan pendapat kepada pihak-pihak yang berkepentingan; (b) mendorong desa pakraman untuk mengendalikan investasi di wilayahnya. Dorongan tersebut dituangkan dalam Keputusan MDP Bali Nomor 050/Kep/Psm-1/MDP Bali/III/2006 yang menegaskan bahwa setiap investasi di wilayah desa pakraman wajib mendapat rekomendasi dari desa pakraman. (3) Upaya yang dapat dilakukan oleh MDP Bali dalam penyelesaian konflik di bidang investasi kepariwisataan di wilayah desa pakraman adalah menjadi mediator dalam penyelesaian konflik yang dilakukan oleh para pihak.

Kata kunci: Majelis Desa Pakraman, investasi kepariwisataan, desa pakraman

\section{PENDAHULUAN}

\subsection{Latar Belakang}

Tidak dapat dibantah bahwa kepariwisataan Bali menimbulkan dampak yang signifikan bagi kehidupan masyarakat Bali, baik yang berupa dampak positif maupun negatif. Perkembangan kepariwisataan Bali diakui telah memberikan kontribusi yang besar bagi kemajuan ekonomi daerah, ditandai oleh meningkatnya berbagai kegiatan ekonomi, terbukanya peluangkerjadankesempatanberusaha, meningkatkan penyerapan tenaga kerja, dan lain-lain. Dari hasil yang diberikan oleh kunjungan wisatawan yang terus meningkat, kepariwisataan Bali juga memberi sumbangan yang signifikan bagi penerimaan devisa negara sehingga dapat dimanfaatkan oleh pemerintah untuk meningkatkan kesejahteraan rakyat.

Karena diyakini bahwa kepariwisataan dapat mengantarkan masyarakat kearah masyarakat yang lebih maju dan sejahtera, maka pembangunan kepariwisataan Bali terus dipacu. Hal ini, antara lain tercermin dari semakin meningkatnya nilai investasi di sektor pariwisata yang mengucur di daerah Bali. Penanaman investasi kepariwisataan terus meningkat melalui pembangunanpembangunan fasilitas-fasilitas kepariwisataan, seperti hotel, villa, restoran, dan lain-lain. Pembangunan fasilitas-fasilitas kepariwisataan dengan penamaman investasi dalam sekala kecil maupun besar tidak hanya terjadi di daerah-daerah perkotaan melainkan juga telah merambah sampai di pelosok-pelosok desa.

Masifnyapertumbuhan investasi pariwisata tersebut pada tataran realitas terlihat dalam perubahan bentang lahan pulau Bali secara drastis. Daerah pesisir, daerah bantaran sungai, perbukitan, dan pegunungan; bahkan hutan yang berfungsi sebagai daerah resapan air pun tidak lepas dari sasaran lokasi pembangunan fasilitas pariwisata. Perubahan fungsi - fungsi lahan yang sangat pesat, bukan saja menjadi ancaman serius terhadap eksistensi para petani yang sejak lama bergantung pada lahan pertanian sawah, tetapi juga mengakibatkan perubahan struktur 
pekerjaan yang rentan menciptakan masalah pengangguran. ${ }^{3}$

Di samping itu, masuknya berbagai kepentingan ke wilayah perdesaan sebagai akibat maraknya pembangunan fasilitas kepariwisataan rentanmenimbulkanbenturan-benturan kepentingan yang di beberapa tempat terbukti bereskalasi menjadi konflik.

Kondisi-kondisi di atas dapat dipandang sebagai dampak negatif dari kepariwisataan Bali sebab berbagai kondisi di atas di samping sangat potensial mengubah wajah Bali menjadi destinasi pariwisata yang jauh dari nilai-nilai pariwisata budaya, juga dapat mengubah nilainilai dan perilaku masyarakat Bali yang dikenal menjunjung tinggi nilainilai kerukunan (suka damai) menjadi masyarakat yang menjauhi nilai-nilai tersebut.

Sejatinya, kehidupan sosial budaya masyarakat dan pariwisata di Bali merupakan dua hal yang tidak dapat dipisahkan. Komponen sosial budaya masyarakat adalah modal utama dalam pengembangan pariwisata Bali. Di dalam jaringan komponen tersebut, budaya agraris dan sosial-religius yang terwujud dalam tatanan kehidupan masyarakat Bali yang diwadahi oleh berbagai organisasi tradisional, seperti subak, desa pakraman, banjar, dadia, dan

\footnotetext{
N. Sutawan, 1997. Strategi Pengembangan Subak sebagai Lembaga Irigasi Tradisonal di Bali. Dalam Pitana (editor). Subak Sistem Tradisonal di Bali, sebuah Canang Sari. Denpasar: Upada Sastra
}

kelompok-kelompok fungsional (sekeha-sekeha) berfungsi sebagai pilar utama penyangga struktur sosial budaya yang ada. Artinya, faktor kunci keberhasilan pembangunan pariwisata Bali terletak pada keberlangsungan dua pranata tradisional tersebut. Idealnya pengembangan pariwisata Bali semestinya diarahkan agar mampu menciptakan pola hubungan saling menguntungkan (simbiotik mutualistik) antara elemen-elemen desa pakraman dengan industri pariwisata. Dengan demikian pariwisata diharapkan akan menjadi bagian hidup dan mempunyai makna/ memberikan manfaat bagi kehidupan masyarakat desa pakraman itu sendiri. ${ }^{4}$

Pengorganisasian kehidupan masyarakat Bali tidak dapat dipisahkan dari pengaruh desa pakraman sebagai organisasi atau kesatuan masyarakat hukum adat di Bali yang mempunyai fungsi sosial relegius. Desa pakraman dapat dikatakan sebagai benteng budaya Bali, karena dalam desa pakramanlah segala aktivitas budaya itu tumbuh, berkembang dan bertahan. Dewasa ini, secara yuridis kedudukan desa pakraman diakui berdasarkan Peraturan Daerah Provinsi Bali Nomor 3 Tahun 2001 sebagaimana telah diubah dengan peraturan Daerah Nomor 3 Tahun 2003 (selanjutnya disebut Perda Desa Pakraman). Secara sosiologis, desa pakraman sesungguhnya adalah

4 Timothy, D.J., dan Boyd, S. W. 2003. Heritage Tourism. $1^{\text {st Edition. England: Pearson }}$ Education Limited. 
unit kesatuan masyarakat yang sudah ada, hidup dan berkembang di Bali sejak masa pra-kerajaan dan tetap bertahan sampai sekarang.

Selama ini, desa pakraman terbukti mempunyai kemampuan untuk mempertahankan eksistensinya ditengah berbagai permasalahan dan tantangan yang telah dihadapinya sejak berabad-abad.Namun, seiring dengan perkembangan jaman, permasalahan dan tantangan yang dihadapi oleh desa pakraman semakin berat dan komplek, baik yang bersifat internal maupun eksternal.Tantangan internal antara lain berubahnya nilainilai, sikap dan perilaku warga desa pakraman sebagai akibat dari tuntutantuntutan perkembangan politik (lokalnasional), ekonomi, sosial dan budaya. Perkembangan-perkembangantersebut tidak bisa dilepaskan dari pengaruh perkembangan zaman di era globalisasi sekarang ini. Tantangan yang bersifat eksternal, antara lain berupa serbuan investasi ke wilayah desa pakraman yang dapat saja menimbulkan dampak ikutan yang tidak dikehendaki, seperti perubahan fungsi lahan yang tidak terkendali, terjadinya berbagai macam konflik, baik konflik yang berdimensi internal (antara sesama warga desa pakraman) ataupun yang berdimensi eksternal (antara desa pakraman dengan investor dan atau pemerintah).

Sebelum tahun 2004, setiap permasalahan dan tantangan yang terjadi di desa pakraman dihadapi sendiri-sendiri oleh desa pakraman yang bersangkutan dengan berlandaskan kepada otonomi yang dimilikinya. Mengingat permasalahan dan tantangan yang dihadapi desa pakraman semakin berat, tentu saja dewasa ini dan ke depan, permasalahan dan tantangan itu tidak dapat lagi dihadapi sendiri-sendiri. Misalnya, permasalahan investasi yang masuk wilayah desa pakraman.Permasalahan tersebut tidak dapat lagi dihadapi secara sendiri-sendiri oleh desa pakraman karena menyangkut kebijakan dan regulasi dari pemerintah.

Sehubungan dengan penyelesaianpermasalahan-permasalahanyang dihadapi oleh desa pakraman, pada tahun 2004 telah dibentuk Majelis Desa Pakraman (MDP) yang merupakan wadah tunggal desa pakraman seluruh Bali. Secara yuridis, pembentukan MDP merupakan amanat Peraturan Daerah Provinsi Bali Nomor 3 Tahun 2001 tentang Desa Pakraman, tetapi secara faktual baru bisa direalisasikan pada tahun 2004. Secara struktural, MDP mempunyai susunan bertingkat, mulai tingkat kecamatan terdapat MDP tingkat kecamatan yang lazim disebut Majelis Alit Desa Pakraman (MADP); di tingkat kabupaten terdapat Majelis Madya Desa Pakraman (MMDP); dan di tingkat provinsi terdapat Majelis Utama Desa Pakraman (MUDP) Provinsi Bali.

Dengan mencermati perkembanganini,problemyuridisyangmuncul adalah bagaimana MDP memainkan perannya dalam penyelesaian masalahmasalah yang dihadapi oleh desa pakraman, khususnya masalah yang 
berkaitan dengan investasi di wilayah desa pakraman. Permasalahanpermasalahan yang perlu diteliti secara mendalam adalah berkaitan dengan peranan MDP dalam pelaksanaan investasi di wilayah desa pakraman serta upaya apa yang dapat dilakukan oleh MDP apabila terjadi konflik di bidang investasi kepariwisataan

\subsection{Perumusan Masalah}

Berdasarkan latar belakang yang telah diuraikan dapat di tarik rumusan masalah adalah sebagai berikut:

1. Faktor-faktor apakah yang mempengaruhi pelaksanaan investasi kepariwisataan di wilayah desa pakraman?

2. Bagaimana peran Majelis Desa Pakraman (MDP) Bali dalam pelaksanaan investasi kepariwisataan di wilayah desa pakraman?

3. Upaya-upaya apakah yang dapat dilakukan oleh Majelis Desa Pakraman (MDP) Bali dalam penyelasaian konflik di bidang investasi kepariwisataan di wilayah desa pakraman?

\subsection{Tujuan Penelitian}

Berdasarkan latar belakang yang telah diuraikan, tujuan penelitian ini sebagai berikut:

1. Untuk menganalisis faktor yang mempengaruhi pelaksanaan investasi kepariwisataan di wilayah desa pakraman
2. Untuk menganalisis peran MDP Bali dalam pelaksanaan investasi kepariwisataan di wilayah desa pakraman

3. Untuk menganalisis upaya yang dapat dilakukan oleh MDP Bali dalam penyelesaian konflik di bidang investasi kepariwisataan.

\section{METODE PENELITIAN}

Penulisan ini dilakukan berdasarkan hasil penelitian yang menggunakan metode penelitian hukum normatif. Permasalahan yang diajukan dikaji berdasarkan normanorma yang tertuang dalam peraturan perundang-undangan.Jenis pendekatan yang digunakan dalam penulisan ini adalah pendekatan undang-undang (statute aprroach) dan pendekatan konseptual (conceptual aprroach).$^{5}$

Sebagai bahan hukum primer digunakan Peraturan Daerah Provinsi Bali Nomor 1 Tahun 2001 sebagaimana telah diubah dengan peraturan Daerah Nomor 3 Tahun 2003. Di samping itu, untuk mengkaji peran Majelis Desa Pakraman dalam penelitian ini juga dikaji Anggaran Dasar Anggaran Rumah Tangga Majelis Desa Pakraman serta Keputusan Majelis Desa Pakraman yang relevan. Sebagai bahan hukum sekunder, dalam penulisan ini digunakan beberapa literatur yang relevan sebagaimana disebutkan pada bagian akhir tulisan ini.

\footnotetext{
Peter Mahmud Marzuki, 2011, Penelitian Hukum, Edisis Revisi, Kencana Predana Group, Jakarta, hlm 136 \& hlm. 177.
} 
Pembahasan dan penyajian dalam penulisan ini dilakukan secara deskriptif analitis, yaitu dengan menggambarkan peran normatif Majelis Desa Pakraman Bali dalam pelaksanaan investasi di wilayah desa pakraman disertai analisisanalisis berdasarkan argumentasi yang dibangun berdasarkan norma, teori dan konsep yang relevan.

III. HASIL DAN PEMBAHASAN 3.1 Faktor yang Mempengaruhi Pelaksanaan Investasi

Kepariwisataan Di Wilayah Desa Pakraman

Secara umum konsep pariwisata yang dikembangkan di Bali didasarkan pada falsafah budaya dan adat istiadat sebagai daya tarik kepariwisataan Beberapa potensi yang dimiliki oleh Desa Pakraman dalam menunjang pariwisata adalah adanya struktur pola menetap di kawasan pariwisata yang dilandasi oleh konsep Tri hita karana, Tri mandala, Tri angga, dan Hulu teben. Konsep-konsep ini menampilkan corak yang unik dan khas dalam tatanan kehidupan masyarakat Bali.

Dalam perkembangan pariwisata Bali, faktor yang mempengaruhi pelaksanaan investasi dalam bidang pariwisata pada umumnya adalah karena daya tarik Bali sebagai destinasi pariwisata yang tersohor di seluruh dunia.Sebagaimana diketahui, keterkenalan Bali sebagai salah satu destinasi pariwisata dunia disebabkan karena faktor alamnya yang indah, penduduknya yang ramah, dan budaya Bali yang unik dan mempunyai nilai tinggi. Faktor lainnya adalah faktor kebijakan pemerintah yang "wellcome": terhadap investasi kepariwisataan, melalui kebijakan dan regulasi yang mendukung investasi kepariwisataan dari Pemerintah Pusat maupun Pemerintah Daerah.

Sebagai salah satu contoh, dapat dikemukakan perkembangan kepariwisataan di Desa Pakraman Ubud. Perkembangan kepariwisataan di daerah ini secara historis telah di awali sejak pemerintahan Raja Ubud pada tahun 1920-an. Ketertarikan wisatawan untuk datang dan ada beberapa diantaranya bermukim di Ubud disebabkan karena alam fisik Ubud yang indah dan asri didukung oleh karakter masyarakat yang ramah tamah dengan budayanya yang unik dan bernilai tinggi. Seperti diketahui, Ubud sejak dulu sampai sekarang dikenal sebagai daerah seni yang sangat terkenal sampai manca negara. Perkembangan kepariwisataan Ubud semakin mantap dengan ditetapkannya Ubud sebagai Daerah Kawasan Wisata melalui SK Bupati Gianyar No 29 Tahun 1988 tertanggal 10 Februari 1988 dan SK Gubernur Bali No 20 Tahun 1993. Regulasi ini kemudian menyebabkan semakin meningkatnya pembangunan fasilitas kepariwisataan di Ubud, seperti restoran, pondok wisata, sampai hotel berbintang, Pembangunan fasilitas - fasilitas 
kepariwisataan tersebut tentu saja memerlukan investasi, baik dalam skala kecil, sedang dan besar. Berikut ini ditampilkan data perkembangan fasilitas kepariwisataan di Desa Pakraman Ubud.

Tabel 1

Perkembangan Sarana Kepariwisataan

Desa PakramanUbud, 2005- 2014

\begin{tabular}{|c|l|c|c|c|}
\hline No. & Fasilitas Kepariwistaan & 2005 & 2010 & 2014 \\
\hline 1 & Hotel Berbintang 3 & 3 & 5 & 7 \\
\hline 2 & Hotel Berbintang 1 & 3 & 3 & 6 \\
\hline 3 & Pondok wisata & 466 & 486 & 501 \\
\hline 4 & Pondok Melati & 211 & 221 & 241 \\
\hline 5 & Restaurant/café & 278 & 280 & 295 \\
\hline
\end{tabular}

Sumber; Dinas Pariwisata Kabupaten Gianyar Tahun 2014

Tabel 2

Sarana dan Prasarana Kepariwisataan Pendukung di Desa PakramanUbud

\begin{tabular}{|l|l|c|}
\hline No & \multicolumn{1}{|c|}{ Nama Jenis Sarana } & Jumlah Unit \\
\hline 1 & Seni Tari dan Tabuh & 78 \\
\hline 2 & Museum & 3 \\
\hline 3 & Gallery Sedang dan Kecil & 21 \\
\hline 4 & Art shop / Kedai seni & 163 \\
\hline 5 & Travel agent sedang dan kecil & 28 \\
\hline 6 & Transportasi privat & 568 \\
\hline 7 & Rumah Therapy / massage & 32 \\
\hline 8 & Pasar Umum & 1 \\
\hline 9 & Istana & 1 \\
\hline 10 & Pura & 6 \\
\hline
\end{tabular}

Sumber; Data diolah dari DIPARDA Kab. Gianyar dan Profill DeaaPakramanUbud, 2014

Berkaitan dengan pelaksanaan investasi kepariwisataan di wilayah (palemahan) desa pakraman, secara normatif desa pakraman mempunyai wewenang untuk menentukan pelaksanaan investasikepariwisataan di wilayahnya. Sesuai dengan pengertian desa pakraman yang dirumuskan dalam Pasal 1 angka (4) Perda Desa Pakraman, maka desa pakraman sebagai kesatuan masyarakat hukum adat yang mempunyai wilayah tertentu berhak mengurus rumah tangganya sendiri. Dengan diakuinya bahwa desa pakraman "berhak mengurus rumah tangganya sendiri”, maka hal itu berarti bahwa desa pakraman mempunyai otonomi mengurus dirinya sendiri, termasuk dalam menentukan peruntukan wilayah (palemahan) desa pakraman.

Kewenangan desa pakraman dalam mengurus wilayahnya kemudian secara spesifik disinggung lagi dalam Pasal 6 Perda Desa Pakraman yang menentukan bahwa, "Desa pakraman mempunyai wewenang...turut serta menentukan setiap keputusan dalam pelaksanaan pembangunan yang ada di wilayahnya terutama yang berkaitan dengan Tri Hita Karana". Berdasarkan ketentuan ini berarti bahwa desa pakraman dapat mempengaruhi pelaksanaan investasi kepariwisataan di wilayahnya. Lebih spesifik lagi, desa pakraman dapat menolak ataupun menerima pelaksanaan investasi kepariwisataan di wilayahnya. Hanya saja, Perda Desa Pakraman tidak menjelaskan lebih lanjut bagaimana cara pelaksanaan ketentuan Pasal 6 tersebut.

Dilihat dari mekanisme yang lazim berlangsung di desa pakraman, setiap keputusan desa pakraman selalu diambil berdasarkan musyawarah mufakat seluruh anggota desa pakraman (kerama desa), musyawarah mana dipimpin oleh Bendesa (Kepala Desa Pakraman). Acara musyawarah kerama desa pakraman tersebut 
dilakukan secara melembaga dalam suatu paruman desa atausangkepan desa. Dalam paruman desa tersebut, setiap permasalahan dibicarakan/ dimusyawarahkan secara demokratis untuk kemudian dapat diambil keputusan. Setiap keputusan paruman desa yang mempunyai kekuatan mengikat semua kerama desa disebut pararem, yang mempunyai kekuatan sama dengan awig-awig.

Setiap keputusan desa pakraman, juga tidak bisa lepas dari awig-awig desa pakraman. Menurut Tjok Istri Putra Astiti, awig-awig tidak lain dari patokan-patokan tingkah laku yang dibuat oleh masyarakat yang bersangkutan berdasarkan rasa keadilan dan kepatutan yang hidup dalam masyarakat yang bersangkutan ${ }^{6}$ Berdasarkan Pasal 1 Perda Desa Pakraman, awig-awig adalah: “... aturan yang dibuat oleh krama desa pakraman dan atau krama banjar pakraman yang dipakai sebagai pedoman dalam pelaksanaan Tri Hita Karana sesuai dengan desa mawacara dan dharma agama di desa pakraman/ banjar pakraman masing-masing". Dengan demikian, awig-awig desa pakraman juga dapat mempengaruhi pelaksanaan investasi kepariwisataan di wilayah desa pakraman. Apabila awig-awig desa pakraman melarang dilakukannya pembangunan fasilitas kepariwisataan di wilayahnya, maka pelaksanaan investasi kepariwisataan

Tjok Istri Putra Astiti, 2005, Pemberdayaan Awig-awig Menuju Ajeg Bali, Lembaga Dokumentasi dan Publikasi Fakultas Hukum Universitas Udayana, hlm. 9. di wilayah desa pakraman tidak mudah untuk dilakukan., bahkan akan mendapat penolakan dari masyarakat desa pakraman. Sebaliknya, apabila awig-awig desa pakraman memberi peluang dilakukannya pembangunan fasilitas kepariwisataan di wilayah desa pakraman maka peluang pelaksanaan investasi di wilayah itu sangat besar.

\subsection{Peran MDP Bali dalam Pelaksanaan Investasi Kepariwisataan Di Wilayah Desa Pakraman}

Dari uraian di atas sudah jelas mengenai peranan desa pakraman dalam pelaksanaan investasi kepariwisataan di wilayah desa pakraman, yaitu dapat menolak atau menerima pelaksanaan investasi tersebut.Hal itu sesuai dengan otonomi desa pakraman yang berhak mengurus wilayahnya (palemahan) sendiri. Sehubungan dengan adanya Majelis Desa Pakraman sebagai wadah tunggal desa pakraman seluruh Bali, maka penting dipahami peran MDP dalam pelaksanaan investasi di wilayah desa pakraman.

Untuk melihat peran yang dapat dimainkan oleh MDP Bali dalam pelaksanaan investasi kepariwisataan di wilayah desa pakraman, maka terlebih dahulu harus dipahami mengenai tugas dan wewenang MDP. Setelah itu baru dapat dipahami mengenai peran MDP. Berdasarkan Pasal 16 Perda Desa Pakraman, MDP mempunyai tugas: (a) mengayomi adat istiadat; (b) memberikan saran, usul 
dan pendapat kepada berbagai pihak, baik perorangan, kelompok/lembaga termasuk pemerintah tentang masalahmasalah adat; (c) melaksanakan setiap keputusan-keputusan paruman dengan aturan-aturan yang ditetapkan; (d) membantu penyuratan awig-awig; dan melaksanakan penyuluhan adat istiadat secara menyeluruh. Untuk dapat mengemban tugas-tugas berat tersebut, Perda Desa Pakraman memberikan beberapa wewenang kepada MDP, yaitu: (a) memusyawarahkan berbagai hal yang menyangkut masalah-masalah adat dan agama untuk kepentingan desa pakraman; (b) sebagai penengah dalam, kasus-kasus adat yang tidak dapat diselesaikan pada tingkat desa; dan (c) membantu penyelenggaraan upacara keagamaan di kecamatan, kabupaten/kota, dan provinsi.

Menurut Wayan P. Windia, MDP mempunyai peran yang strategis, yaitu: (1) memperkuat kelembagaan desa pakraman yang dapat dilakukan dengan bekerja sama dengan Pemerintah dalam usaha melestarikan "jiwa desa pakraman" sekaligus "jiwa Bali"; (2) sebagai media komunikasi antar-kerama desa pakraman dan antar-desa pakraman yang ada di Bali; (3) menjadi filter terhadap pengaruh luar desa pakraman; (4) secara proaktif membangun komunikasi dan hubungan baik dengan organisasi lain di luar desa pakraman dalam mewujudkan kedamaian Bali $^{7}$

7 Wayan P. Windia, 2011, "Peran Strategis MDP Bali dalam Menjawab Tantangan Bali Masa Depan", dalam Himpunan Hasil-hasil Pesamuan Agung III MDP Bali, Majelis utama Desa Pakraman (MDP) Bali, hlm. 15-16.
Vol. 5, No. 2 : 353 - 367

http://ojs.unud.ac.id/index.php/jmhu
Dari rangkaian ketentuan normatif di atas, jelas MDP tidak dapat secara langsung berperan dalam pelaksanaaninvestasikepariwisataandi wilayah desa pakraman. Pelaksanaan investasi apapun di wilayah desa pakraman sepenuhnya merupakan kewenangan desa pakraman, sebab keberadaan MDP tidak meniadakan otonomi desa pakraman. Sesuai tugas MDP sebagaimana ditentukan dalam Pasal 16 ayat (1) Perda Desa Pakraman, MDP Bali dapat berperan dalam pelaksanaan investasi di wilayah desa pakraman dengan memberi saran, usul dan pendapat kepada pihak-pihak yang berkepentingan, dalam hal ini desa pakraman, investor ataupun kepada pemerintah tentang pelaksanaan investasi. Hal ini dapat dilakukan sebab investasi di wilayah desa pakraman juga menyentuh masalah adat, yaitu menyangkut wilayah (palemahan) desa pakraman sebagai benteng budaya Bali.

Di samping itu, sesuai dengan ketentuan pasal 16 ayat (2) Perda Desa pakraman, MDP Bali juga dapat berperan secara tidak langsung dalam menghadapi masalah pelaksanaan investasi di wilayah desa pakraman, yaitu dengan memusyawarahkan masalah tersebut untuk diambil sebuah keputusan yang pada gilirannya dapat menjadi pedoman bagi seluruh desa pakraman di Bali. Sesuai dengan Pasal 21 Anggaran Dasar/Anggaran Rumah Tangga MDP, terdapat tiga forum pertemuan MDP sebagai sarana untuk mengambil keputusan, yaitu (1) 
Surnal
Magister Hukum USSNN 2502-3101
(UDAYANANA MASTER LAW JOURNAL)

Paruman (Paruman Agung, Paruman madya, Paruman Alit), (2) Pesamuan dan (3) Pesangkepan (Pasal 21). Dalam pasal 22 ayat (4) disebutkan bahwa keputusan yang mengikat seluruh desa pakraman di Bali diambil dalam forum pertemuan pada level Paruman Agung ${ }^{8}$. Dalam praktek, keputusan-keputusan strategis MDP yang menyangkut masalah-masalah adat diambil dalam forum musyawarah yang dinamai Pesamuan Agung, Hal itu dapat dilihat dalam buku Himpunan Hasil-hasil Pesamuhan Agung MDP Bali yang diterbitkan oleh Majelis Utama Desa Pakraman (MDP) Bali tahun 2010 ataupun yang diterbitkan tahun $2011^{9}$

Berkaitan dengan pelaksanaan investasi di wilayah desa pakraman, MDP Bali telah mengambil suatu keputusan yang strategis melalui Pesamuan Agung I MDP Bali yang diselenggarakan tanggal 3 Maret 2006. Keputusan yang dituangkan dalam Keputusan MDP Bali Nomor 050/Kep/Psm-1/MDP Bali/III/2006 menyatakan sebagai berikut:

1. Setiap investasi di wewidangan/ wawengkon (wilayah) desa

Majelis Utama Desa Pakraman (MDP) Bali, 2004, Anggaran Dasar Anggaran Rumah Tangga Majelis Desa Pakraman, hlm. 12-13.

9 Buku Himpunan hail-hasil Pesamuhan Agung MDP Bali yang terbit tahun 2010 berisi (1) Keputusan MDP Bali Nomor 050/Kep/Psm1/MDP Bali/III/2006 tentang Hasil-hasil Pesamuan Agung I MDP Bali; (2) Keputusan MUDP Bali Nomor 01/Kep/Psm-2/MDP Bali/X/2007 tentang Hasil-hasil Pasamuan Agung II MDP Bali; sedangkan buku terbitan 2011 berisi Keputusan Majelis Utama Desa Pakraman Bali Nomor 01/Kep/Psm-3/MDP Bali $/ \mathrm{x} / 2010$ tentang Hasil-hasil Pesamuan Agung III MDP Bali.
Vol. 5, No. $2: 353$ - 367

http://ojs.unud.ac.id/index.php/jmhu

pakraman patut mendapat rekomendasi desa pakraman, selain persetujuan dari instansi terkait lainnya.

2. rekomendasi diberikan oleh bendesa berdasarkan keputusan parumankrama desa pakraman ${ }^{10}$ Dalam Keputusan MDP Bali Nomor 050/Kep/Psm-1/MDP Bali/III/2006 tidak secara spesifik disebutkan dasar pertimbangan dikeluarkannya keputusan tersebut, kecuali hanya secara umum disebutkan bahwa keputusan tersebut dipandang perlu dibuat karena semakin kompleksnya permasalahan adat dan hukum adat Bali. Tetapi secara tersirat dapat dipahami bahwa keputusan tersebut dilatarbelakangi oleh suatu kekhawatiran tidak terkendalinya pelaksanaan investasi di wilayah desa pakraman, kekhawatiran mana dapat diterjemahkan dari frasa "semakin kompleksnya permasalahan adat.." sebagaimana dituangkan dalam konsideran menimbang dari keputusan tersebut.

Mengenai tujuan dikeluarkannya keputusan tersebut, secara eklplisit disebutkan dalam konsideran maupun dalam diktum, yaitu untuk dijadikan pedoman bagi segenap prajuru desa ataupun jajaran MDP Bali dalam menghadapi masalah-masalah adat ${ }^{11}$.

\footnotetext{
Majelis Utama Desa Pakraman(MUDP) Bali, 2007, Himpunan Hasil-hasil Pesamuhan Agung I dan II MDP Bali, hlm. 20.

11 Konsideran point "menimbang Keputusan Majelis Utama Desa Pakraman (MDP) Bali Nomor 050/Kep/Psm-1/MDP Bali/III/2006, dalam Majelis Utama Desa Pakraman (MUDP) Bali, ibid, hlm. 3
} 
Sifat yang lunak dari keputusan ini, yaitu hanya sebagai pedoman, dapat dipahami sebab MDP tidak boleh meniadakan otonomi desa pakraman. Agar putusan tersebut mengikat desa pakraman maka masih perlu dituangkan lebih lanjut dalam awig-awig desa pakraman.

Sesungguhnya, tidak ada hal baru dari keputusan ini. Keputusan ini hanya menegaskan kembali bahwa desa pakraman mempunyai otonomi terhadap wilayahnya, sehingga berhak mengurusnya sendiri. Melalui keputusan ini MDP Bali mengingatkan desa pakraman di seluruh Bali bahwa berdasarkan otonomi yang dimiliki setiap desa pakraman dapat mengendalikan pelaksanaan investasi di wilayahnya. Agar pelaksanaan investasi di wilayah desa pakraman dapat dikendalikan oleh desa pakraman itu sendiri sehingga tidak merugikan desa pakraman, maka pelaksanaan investasi tersebut haruslah mendapatkan persetujuan dari desa pakraman. Persetujuan desa pakraman tersebut diwujudkan dalam bentuk rekomendasi desa pakraman yang ditandatangani oleh bendesa.

\subsection{Upaya Yang Dapat Dilakukan Majelis Desa Pakraman untuk Menyelesaikan Konflik di Bidang Investasi Kepariwisataan}

Dengan masuknya investasi kepariwisataan di wilayah desa pakraman, tidak dapat dihindari hadirnya berbagai kepentingan di wilayah desa pakraman. Berbagai kepentingan tersebut dapat saja saling berbenturan dan bereskalasi menjadi konflik. Dengan mengutip Boulding, I Made Widnyana menyatakan bahwa konflik adalah “...Suatu situasi dari persaingan dimana para pihak menyadari adanya ketidakcocokan potensial dari posisi-posisi yang akan datang, dan dimana setiap pihak menginginkan untuk menepati posisi yang tidak sesuai dengan keinginankeinginan dari pihak lainnya". ${ }^{12}$

Berkaitan dengan konflik sebagai akibat pelaksanaan investasi di wilayah desa pakraman, konflik dapat terjadi antara desa pakraman di satu pihak melawan investor atau pemerintah dipihak lain. Di samping itu, konflik juga dapat terjadi antara desa pakraman yang satu dengan yang lainnya atau antara banjar yang satu dengan banjar lainnya dalam satu desa pakraman. Dalam perspektif Comaroff dan Roberts bentuk konflik ini disebut konflik intrahouse ${ }^{13}$. Akibat masuknya aktivitas-aktivitas kepariwisataan di suatu wilayah desa pakraman, dapat juga menimbulkan konflik antara individu dalam desa pakraman, bahkan konflik antara individu anggota desa pakraman melawan kelompoknya (banjar atau desa pakraman),

12 I Made Widnyana, 2009, Alternatif PenyelesaianSengketa(ADR),FikahatiAneskaBANI, Jakarta,hlm.52.

13 Valerine J.L Kriekhoff, 2001, "Meditasi (Tinjauan dari Segi Amtropologi Hukum)", dalam T.O Ihromi (Penyunting), Antropologi Hukum Sebuah Bunga Rampai, Yayasan Obor Indonesia,Jakarta,hlm.225. 
Penyebab konflik pun dapat beragam. Dalam hal konflik antara desa pakraman melawan investor, konflik antara lain dapat terjadi karena perbedaan pendapat dalam mempersepsikandan menyikapi pelaksanaan kesepakatan kerja sama antara desa pakraman dan investor; pelaksanaan investasi yang tidak sesuai dengan peraturan adat, ketidakpuasan terhadap realisasi dari komitmen yang sudah dicapai oleh desa pakraman dan investor, serta kepentingan internal masyarakat di desa pakraman yang tidak diakomodasi oleh pihak investor, dan lain-lain. Konflik yang terjadi antara desa pakraman satu dengan lainnya dapat terjadi, misalnya, muncul kepermukaan sebagai konflik batas wilayah. Konflik antar-individu anggota desa pakraman ataupun individu anggota desa pakraman melawan kelompoknya (banjar atau desa pakraman) potensial terjadi sebagai akibat perbedaan persepsi terkait hak dan kewajiban kerama desa sebagai dampak masuknya kegiatan pariwisata di wilayah desa pakraman yang bersangkutan. Misalnya, seorang anggota desa pakraman tidak mampu lagi menunaikan kewajibannya hadir untuk ngaturangayah secara fisik di banjar atau desa karena bekerja di hotel atau restoran sehingga dikenakan sanksi oleh banjar atau desa pakraman.

Berbagai macam konflik yang terjadi terkait dengan pelaksanaan investasikepariwisataandiwilayahdesa pakraman idealnya dapat diselesaikan sendiri oleh desa pakraman melalui mekanisme penyelesaian konflik secara adat yang tersedia, misalnya penyelesaianmelaluiparuman/sangkep di tingkat banjar atau desa pakraman. Pada umumnya, penyelesaian konflik melalui mekanisme adat dapat secara efektif menyelesaikan konflik antarindividu dalam kelompok banjar atau desa pakraman, tetapi kurang efektif menyelesaikan konflik yang terjadi dimana kelompok (banjar atau desa pakraman) yang terlibat dalam konflik. Oleh karena itu, karena kompleksitas konflik, bisa saja konflik-konflik yang menyangkut investasi kepariwisataan tidak dapat diselesaikan di tingkat desa pakraman. Dalam situasi demikian, MDP dapat berperan dalam menyelesaikan konflik sesuai dengan landasan normatif yang diatur dalam Perda Desa Pakraman. Berdasarkan ketentuan pasal 16 ayat (2) Perda Desa Pakraman, MDP mempunyai wewenang "sebagai penengah dalam kasus-kasus adat yang tidak dapat diselesaikan pada tingkat desa". Walaupun masalah sengketa investasi adalah persoalan perdata, tetapi sepanjang konflik tersebut menyangkut desa pakraman sebagai pihak yang berkonflik, maka konflik tersebut dapat dikategorikan sebagai kasus adat, sehingga MDP dapat berperan sebagai penengah.

Dilihat dari perspektif model penyelesaian sengketa yang dikenal sebagai Alternative Dispute 
Resolution (ADR), peran yang dapat dilakukan oleh MDP berdasarkan wewenangnya itu berada pada tataran peran sebagai mediator. Bentuk penyelesaiannya disebut mediasi, yaitu proses penyelesaian sengketa antara para pihak yang berkonflik dengan menggunakan bantuan pihak ketiga yang netral sebagai penengah. Pihak ketiga yang menjadi penengah itu hanya berkedudukan sebagai fasilitator untuk merundingkan kepentingankepentingan para pihak, sedangkan keputusan tetap diambil oleh para pihak $^{14}$. Secara yuridis formal, model penyelesaian melalui mediasi diatur dalam Undang-undang Nomor 30 Tahun 1999 Tentang Arbitrase dan Alternatif Penyelesaian Sengketa.

\section{PENUTUP}

\subsection{Simpulan}

Berdasarkan uraian sebelumnya, akhirnya dapat disimpulkan sebagai berikut:

1. Terdapat beberapa faktor yang mempengaruhi pelaksanaan investasi kepariwisataan di wilayah desa pakraman. Di satu sisi, faktor keindahan alam dan kondisi sosial budaya yang unik dan bernilai tinggi dapat menjadi faktor penarik pelaksanaan investasi kepariwisataan di suatu wilayah desa pakraman. Di samping itu, faktor kebijakan dan regulasi pemerintah yang "wellcome" terhadap

$14 \quad$ Ibid., hlm.111. investasi kepariwisataan semakin menyebabkan maraknya pelaksanaan investasi kepariwisataan di wilayah desa pakraman. Di sisi lain, desa pakraman dengan awig-awig (peraturan adat) yang dimiliki dapat menjadi faktor pengendali pelaksanaan investasi kepariwisataan di wilayah desa pakraman yang bersangkutan.

2. Majelis Desa Pakraman (MDP) Bali tidak dapat berperan secara langsung dalam pelaksanaan investasi kepariwisataan di wilayah desa pakraman sebab pelaksanaan investasi di suatu wilayah desa pakraman merupakan otonomi desa pakramanyang bersangkutan. Melalui mekanisme yang ada (paruman desa), desa pakraman dapat saja menerima atau menolak investasi yang masuk di wilayahnya tanpa memerlukan campur tangan MDP Bali. Tetapi secara normatif, MDP dapat berperanmemberikansaran, usulusul dan pendapat kepada para pihak yang berkepentingan (desa pakraman, investor, pemerintah) terhadap pelaksanaan investasi kepariwisataan di wilayah desa pakraman tetapi saran dan usul tersebut tidak mengikat. Peran strategis yang sudah dilakukan oleh MDP Bali adalah mengeluarkan keputusan yang tujuannya mendorong desa 
pakraman seluruh Bali untuk mengendalikan investasi di wilayahnya masing-masing, yaitu dengan menentukan bahwa setiap investasi di wilayah desa pakraman wajib mendapat rekomendasi daridesa pakraman. Dorongan tersebut tertuang dalam Keputusan MUDP Bali Nomor $\quad$ 050/Lep/Psm-1/MDP Bali/III/2006.

3. Upaya yang dapat dilakukan oleh MDP Bali untuk menyelesaikan konflik di bidang investasi kepariwisataan, terutama investasi di wilayah desa pakraman adalah peran sebagai penengah (mediator) antara para pihak yang berkonflik. Hal itu sesuai wewenang yang diberikan oleh Pasal 16 ayat (2) Perda Desa Pakraman.

\subsection{Saran}

Sebagai penutup tulisan ini, akhirnya dikemukakan beberapa saran sebagai berikut.

1. Kepada Pemda Bali disarankan untuk membuat pengaturan secara eksplisit tentang hakhak dan kewajiban investor dan desa pakraman dalam pelaksanaan investasi di wilayah desa pakraman. Di samping itu, Pemda Bali meningkatkan pelatihan dan pendidikan sumber daya manusia di bidang kepariwisataan

2. Kepada MDP Bali disarankan agar mengoptimalkan pemberdayaan desa pakraman agar aspirasi masyarakat dpat tersalur dengan baik terkait dengan pelaksanaan investasi kepariwisataan di wilayah desa pakraman. Dengan begitu diharapkan, konflik yang terjadi antara masyarakat dan investor dapat dihindari.

3. Kepada Investor disarankan bahwa dalam melakukan penanaman modal (investasi) di wilayah desa pakraman hendaknya tidak saja berpatokan pada hukum formal tetapi juga harus memperhatikan awig-awig desa pakraman sebagai aturanaturan lokal yang mengatur hubungan antara desa pakraman dan lingkungan wilayahnya.

\section{DAFTAR PUSTAKA}

AstitiTjok Istri Putra, 2005, Pemberdayaan Awig-awig Menuju Ajeg Bali, Lembaga Dokumentasi dan Publikasi Fakultas Hukum Universitas Udayana.

Majelis Utama Desa Pakraman (MDP)

Bali, 2004, Anggaran Dasar Anggaran Rumah Tangga Majelis Desa Pakraman.

Majelis Utama Desa Pakraman (MDP) Bali. 2007. Himpunan Hasilhasil Pasamuhan Agung I dan II MDP Bali.

Marzuki Peter Mahmud, 2011, Penelitian Hukum, Edisi Revisi, 
Vol. 5, No. $2: 353$ - 367

http://ojs.unud.ac.id/index.php/jmhu

Kencana Prenada Group,

Jakarta.

N. Sutawan, 1997. Strategi

Pengembangan Subak sebagai

Lembaga Irigasi Tradisional

di Bali. Dalam Pitana (editor).

Subak Sistem Tradisional di Bali,

sebuah Canang Sari. Denpasar:

Upada Sastra

Timothy, D.J., dan Boyd, S. W. 2003.

Heritage Tourism. $1^{\text {stEdition. }}$

England: Pearson Education

Limited.

WidnyanaI Made, 2009, Alternatif Penyelesaian Sengketa (ADR), FikahatiAneska-BANI, Jakarta.

Windia Wayan P, 2011, "Peran Strategis MDP Bali dalam Menjawab Tantangan Bali Masa Depan", dalam Himpunan Hasil-hasil Pesamuan Agung III MDP Bali, Majelis Utama Desa Pakraman (MDP) Bali.

Valerine J.L. Kriekhoff, 2001, "Mediasi (Tinjauan dari Segi Antropologi Hukum)", dalam T.O. Ihromi (Penyunting), Antropologi Hukum Sebuah Bunga Rampai, Yayasan Obor Indonesia, Jakarta. 